\title{
Anomalous origin of the deep brachial artery (profunda brachii) observed in bilateral arms: case report
}

\author{
Origem anômala da artéria braquial profunda \\ (profunda brachii) observada em braços bilaterais: relato de caso
}

Rafael Cisne de Paula', Rafael Erthal², Rodrigo Mota Pacheco Fernandes², Marcio Antônio Babinski², Julio Guilherme Silva ${ }^{3}$, Carlos Alberto Araujo Chagas ${ }^{4}$

\begin{abstract}
During an ordinary dissection, a cadaver showed a bilateral anomalous origin of the deep brachial artery, where this vessel appeared like a branching of the subscapular artery with common trunk, which included the posterior circumflex humeral artery. The course and distribution of the deep brachial artery in the back compartment were relatively consistent with previous reports. Arterial variations can be damaged through iatrogenic means if not properly documented. The knowledge of this case is very important in clinical medicine and in surgeries in this compartment to prevent any injury.
\end{abstract}

Keywords: deep brachial artery; anatomical variation; surgery

\begin{abstract}
Resumo
Durante dissecação em prática usual, um cadáver apresentou origem anômala da artéria braquial profunda, na qual este vaso apareceu como um ramo da artéria subescapular com um tronco comum, que incluiu a artéria circunflexa posterior do úmero. $\mathrm{O}$ curso e a distribuição da artéria braquial profunda no compartimento posterior foram relativamente coincidentes com relatos prévios. Variações arteriais podem ser danificadas de maneira iatrogênica se não forem adequadamente documentadas. O conhecimento desse caso é muito importante na prática clínica e em cirurgias nesse compartimento para prevenção de qualquer injúria.
\end{abstract}

Palavras-chave: artéria braquial profunda; variação anatômica; cirurgia.

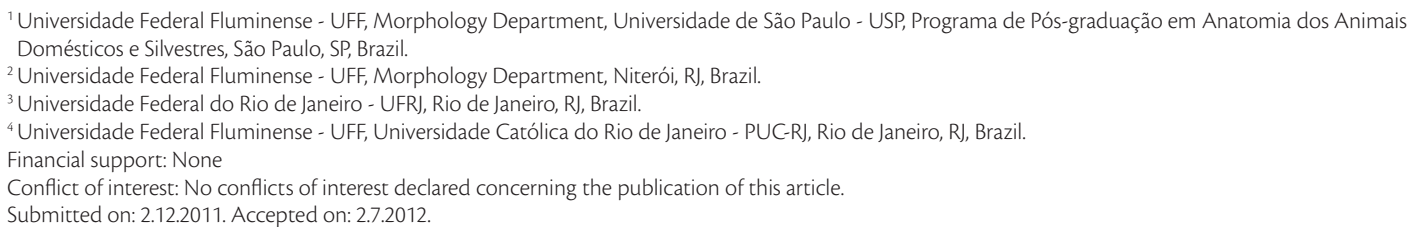




\section{INTRODUCTION}

Anatomical variations in arterial and venous formations are common, mainly due to wrong embryological formation. Several authors have reported variations in vessels of the upper limb presenting some interesting cases ${ }^{1-5}$.

The theory regarding the vascular system development of the upper limb states that it begins at stage 12 . Initially, a capillary plexus enters the limb bud and, in later stages, only one trunk, named the axial artery, supplies the limb and terminal plexus. From this axial artery, which represents the axillary, brachial, and anterior interosseous, the forearm arteries appear successively. The axillary and brachial arteries begin their development at stages 16 and 17 successively and, therefore, anatomical variations including these vessels may have originated at this time ${ }^{6,7}$.

In $55 \%$ of the cases ${ }^{1,2}$, the deep brachial artery (DBA) is the larger branch issued from the brachial artery (BA), and it leaves near the bottom edge of the teres major muscle to penetrate above the medial intermuscular septum on the lower triangular axillary space together with a radial nerve $(\mathrm{RN})^{8,9}$. Several variations in the branching pattern of brachial and axillary arteries have been described, mainly related with vessels of the third part ${ }^{10}$.

In the present paper, we described a rare anatomical variation where the DBA does not arise from the BA below the inferior margin of the teres major muscle, in bilateral arms of a Brazilian cadaver. It has an anomalous origin from the subscapular artery (SA), which is the largest and major branch in the third part of the axillary artery.
The variable branching of axillary artery, position, frequency, distribution, relationship between this branch and brachial plexus would be invaluable resources to surgeons working in the axilla ${ }^{10}$.

\section{CASE REPORT}

During a regular dissection in the Department of Anatomy of the University, a female cadaver of an adult (aged approximately 45 to 55 years-old), fixed in $10 \%$ formalin ( $\mathrm{pH}=7.2$ ), showed a bilateral anomalous origin of the DBA. This cadaver died of causes not related to the vascular system. This report complies with the provisions of the Declaration of Helsinki, made in 1995 (as revised in Edinburgh, 2000).

In the current case, the axillary artery passed normally between the medial and lateral roots of the median nerve and, only after this, it issued a large arterial trunk that gave off the DBA first, slightly below the posterior circumflex humeral artery (PCHA), and continued like a SA (Figure 1). The PCHA appears closer to the axillary nerve (AN) running in the triangular space, the DBA runs toward the back of the axillary compartment with the RN to arrive in the posterior compartment of the arm. The anterior circumflex humeral artery arises from the axillary artery (Figure 2).

There were no other anatomical variations in the axillary region of this cadaver. The patterns described were common in both arms.

\section{DISCUSSION}

Variations in the branching patterns of the major arterial trunks have been reported with an incidence of over $20 \%$ in human adult limbs ${ }^{7}$. Despite this,

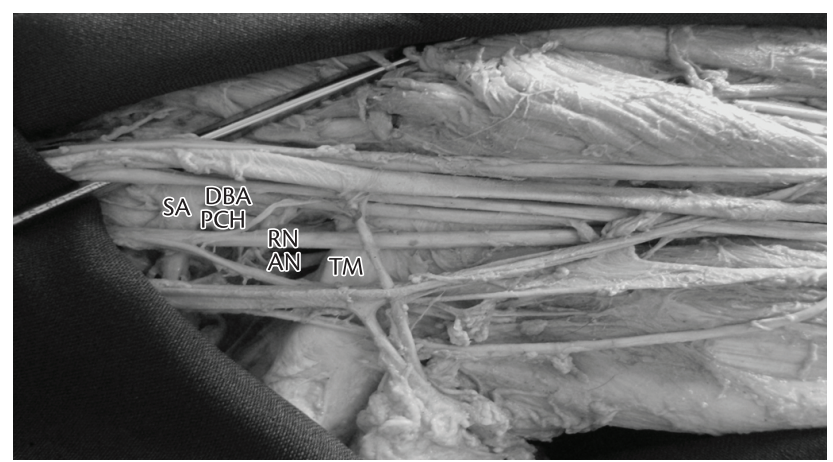

AN: axillary nerve; DBA: deep brachial artery; $\mathrm{PCH}$ : posterior circumflex humeral; $\mathrm{RN}$ : radial nerve; SA: subscapular artery; TM: teres major muscle.

Figure 1. Large arterial trunk that gave off the deep brachial artery first, and slightly below the posterior circumflex humeral artery, which continues like a subscapular artery in the left arm. 


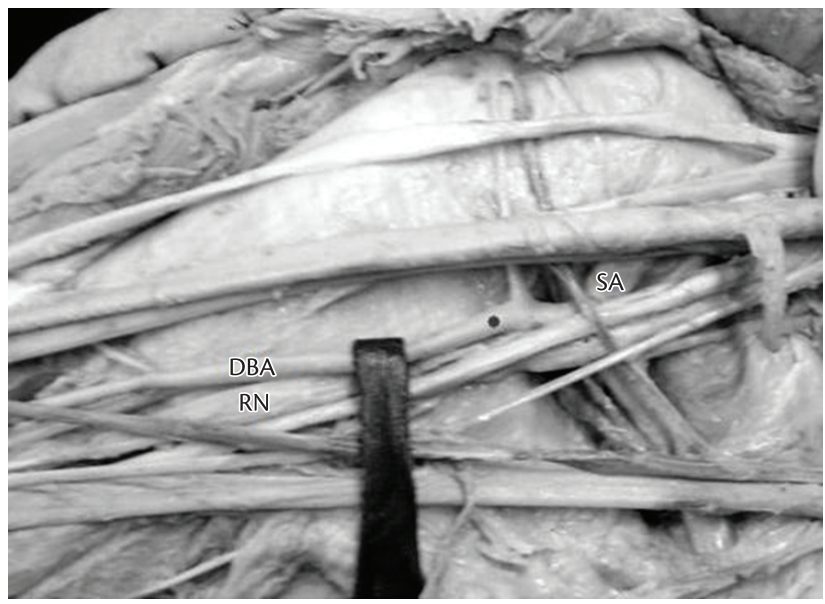

DBA: deep brachial artery; RN: radial nerve; SA: subscapular artery.

Figure 2. Right arm showing the same variations.

several variations in its origin and in the course of the DBA, like other vessels of the upper limb, could be considered. The classical literature had a description, in which the PCHA may arise from or form a common trunk with the SA (15\%). The PCHA may also be a branch of the SA in $10 \%$ and the DBA in $2 \%$ of individuals ${ }^{1,11}$.

Olinger and Benninger observed, by dissecting 166 axillae, the frequency and branching patterns of the axillary artery. They reported that the PCHA originated from the DBA in $8.4 \%$ of the patterns, and it was observed doing so bilaterally $71.4 \%$ of sides . However, when the PCHA originated from DBA, it only traveled through the quadrangular space in $14.3 \%$ of the cases. In $85.7 \%$ of them, when the PCHA arose from the DBA, the triangular interval was seen traversing, then traveling superiorly to supply the deltoid muscle ${ }^{10}$.

Vijayabhaskar et al. reported a case of DBA rising to the subscapular, articular branch to the shoulder joint, anterior and posterior circumflex humeral arteries. This variation is very rare and its incidence is around 0.12 to $3.2 \%$ in the available literature ${ }^{12}$.

In another interesting case report, the superficial brachial and subscapular arteries coexisted in the absence of the normal brachial artery, and the superficial subscapular artery send off the lateral thoracic artery, and then branched off into the thoracodorsal, circumflex scapular, posterior circumflex humeral and finally the DBA ${ }^{2}$.

In other case, a variation in the arterial anatomy of the upper extremities was reported, in which the BA was absent from its origin, and also the DBA ${ }^{6}$.
Appreciation of variations in the upper extremity vasculature is essential to prevent injury, particularly in patients requiring dialysis or undergoing arteriography. Also, it is also important for those patients who need arteriovenous bypass with thigh autogenous access or with grafts, especially when there is the need of axillary-axillary one for hemodialysis ${ }^{13,14}$.

Dalin et al. reported a case of a 76 years-old man, who was submitted surgically for treatment of the DBA aneurysm. Deep brachial aneurysms are extremely rare ${ }^{15}$.

Furthermore, the use of shoulder, axillary, or even abdominal tissue flaps for the reconstruction of cervical and axillary scar contractures, and autogenous tissue breast reconstruction, needs knowledge of patterns and frequency of axillary arterial branches ${ }^{10}$.

The variation reported in this article is very uncommon and has a practical importance for the vascular clinical, surgeon, and radiologist. Besides other health professionals, it should be known for an accurate diagnosis, imaging interpretation, and surgical treatment.

\section{REFERENCES}

1. Bergman RA, Thompson SA, Afifi AK, et al. Compendium of Human Anatomic Variation: Catalog, Atlas and World Literature. Baltimore: Urban \& Schwarzenberg; 1988.

2. Yoshinaga K, Kodama K, Kameta K, et al. Rare variation of the arm artery: coexistence with the superficial brachial and superficial subscapular arteries in the absence of the normal brachial artery. Okajimas Folia Anat Jpn. 2003;80(1):23-7. PMid:12858962. http:// dx.doi.org/10.2535/ofaj.80.23 
3. Cavdar S, Zeybek A, Bayramiçli M. Rare variation of the axillary artery. Clin Anat. 2000;13(1):66-8. http://dx.doi.org/10.1002/ (SICI)1098-2353(2000)13:1<66::AID-CA8 > 3.0.CO;2-M

4. Nakatani T, Tanaka S, Mizukami S. Superficial brachial arteries observed in bilateral arms. Kaibogaku Zasshi. 1996;71(4):308-12. PMid:8968132.

5. Natsis K, Papadopoulou AL, Paraskevas G, Totlis T, Tsikaras P. High origin of a superficial ulnar artery arising from the axillary artery: anatomy, embryology, clinical significance and a review of the literature. Folia Morphol (Warsz). 2006;65(4):400-5. PMid:17171623.

6. Ciervo A, Kahn M, Pangilian AJ, Dardik H, Englewood NJ. Absence of the brachial artery: Report of a rare human variation and review of upper extremity arterial anomalie. J Vasc Surg. 2001;33(1):191-4. http://dx.doi.org/10.1067/mva.2001.112212

7. Rodríguez-Niedenführ M, Burton GJ, Deu J, Sañudo JR. Development of the arterial pattern in the upper limb of staged human embryos: normal development and anatomic variations. J Anat. 2001;199(4):407-17. PMid:11693301.

8. Latarjet $M$, Ruiz-Liard A. Anatomia Humana. 2. ed. São Paulo: Médica Panamericana; 1996.

9. Testut L, Jacob O. Tratado de anatomía topográfica con aplicaciones médicoquirúrgicas. 6th ed. Barcelona: Salvat; 1944.

10. Olinger A, Benninger B. Branching patterns of the lateral thoracic, subscapular, and posterior circumflex humeral arteries and their relationship to the posterior cord of the brachial plexus. Clin Anat. 2010;23(4):407-12. http://dx.doi.org/10.1002/ca.20958

11. Dubreuil-Chambardel, L. Variations des Artères du Membre Superieur. Paris: Masson et Cie; 1926.

12. Vijayabhaskar P, Ritesh R, Shankar PR. Anomalous branching of the axillary artery: A case report. Kathmandu Univ Med J. 2006;4(4):517-9. PMid:18603967.

13. Shindo $S$, Kojima A, Ishimoto $T$, Iyori $K$, Kobayashi $M$, Tada Y. Arterial reconstruction in the upper extremities. Vascular. 2004;12(2):57-61. PMid:15127856.

14. Morsy MA, Khan A, Chemla ES. Prosthetic axillary-axillary arteriovenous straight access (necklace graft) for difficult hemodialysis patients: a prospective single-center experience. J Vasc Surg. 2008;48(5):1251-4. http://dx.doi.org/10.1016/j. jvs.2008.06.064

15. Dalin L, Jingqiang Y, Kun Z, Yunhui C. Surgical treatment of deep brachial artery aneurysm. Ann Vasc Surg. 2011;25(7):983.e13-6. http://dx.doi.org/10.1016/j.avsg.2011.05.006
Correspondence

Carlos Alberto Araujo Chagas

Rua Conde de Bonfim, 100/401, Tijuca, CEP 20520-053, Rio de Janeiro (RJ), Brazil

Fone: +55 (21) 2565-7950/9797-8766

E-mails: carloschagas@sbacvrj.com.br; carloschagas@cremerj.org.br

Author information

RCP MSc. Department of Morphology, Universidade Federa Fluminense (UFF). Graduate Program in Anatomy of Domestic and Wild Animals, Universidade de São Paulo (USP).

RE Department of Morphology, Universidade Federal Fluminense (UFF). Medical student, Universidade Federal Fluminense (UFF). RMPF MD, MSc. Department of Morphology,

Universidade Federal Fluminense (UFF). Assistant professor, Universidade Federal Fluminense (UFF)

MAB PhD. Department of Morphology, Universidade Federal Fluminense (UFF). Associate professor,

Universidade Federal Fluminense (UFF)

JGS PhD. Adjunct professor, Universidade Federal do Rio de Janeiro (UFRJ). CAAC MD, MSc. Angiologist. Adjunct professor, Universidade Federal Fluminense (UFF). Invited professor, Graduate Program in Angiology, Pontifícia Universidade Católica do Rio de Janeiro (PUC-RJ).

Author's contributions Conception and design: RCP, MAB, CAAC Analysis and interpretation: RCP, MAB, JGS, RMPF, CAAC Data collection: RCP, ER, RMPF, MAB, JGS, TFOL, CAAC Writing the article:RCP, ER, RMPF, MAB, JGS, TFOL, CAAC Critical revision of the article: RCP, RMPF, MAB, JGS, CAAC Final approval of the article*: MAB, CAAC Statistical analysis: RCP, ER, RMPF, MAB, JGS, TFOL, CAAC Overall responsibility: CAAC Obtained funding: N/A

*All authors have read and approved the final version submitted to J Vasc Bras. 